\title{
Clinical value of circulating endothelial cells and of soluble CD146 levels in patients undergoing surgery for non-small cell lung cancer
}

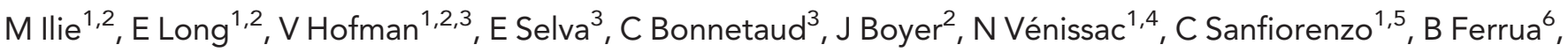 \\ C-H Marquette ${ }^{1,5}$, J Mouroux ${ }^{1,4}$ and P Hofman ${ }^{\star 1,2,3}$ \\ ${ }^{1}$ IRCAN Inserm/CNRS Team 3, CLCC Centre Antoine Lacassagne, University of Nice Sophia Antipolis, Nice, France; ${ }^{2}$ Laboratory of \\ Clinical and Experimental Pathology, Pasteur Hospital, Nice, France; ${ }^{3}$ Tumor Biobank, Pasteur Hospital, Nice, France; \\ ${ }^{4}$ Department of Thoracic Surgery, Pasteur Hospital, Nice, France; ${ }^{5}$ Department of Pneumology, Pasteur Hospital, Nice, France \\ and ${ }^{6}$ Inserm C3M, Archet II Hospital, Nice, France
}

Background: Previous studies indicate that endothelial injury, as demonstrated by the presence of circulating endothelial cells (CECs), may predict clinical outcome in cancer patients. In addition, soluble CD146 (sCD146) may reflect activation of angiogenesis. However, no study has investigated their combined clinical value in patients undergoing resection for non-small cell lung cancer (NSCLC).

Methods: Data were collected from preoperative blood samples from 74 patients who underwent resection for NSCLC. Circulating endothelial cells were defined, using the CellSearch Assay, as CD146 + CD105 + CD45 - DAPI + . In parallel, sCD146 was quantified using an ELISA immunoassay. These experiments were also performed on a group of 20 patients with small-cell lung cancer, 60 healthy individuals and 23 patients with chronic obstructive pulmonary disease.

Results: The CEC count and the plasma level of SCD146 were significantly higher in NSCLC patients than in the sub-groups of controls $(P<0.001)$. Moreover, an increased CEC count was associated with higher levels of sCD146 $(P=0.010)$. Both high CEC count and high sCD146 plasma level at baseline significantly correlated with shorter progression-free survival $(P<0.001$, respectively) and overall survival $(P=0.005 ; P=0.009)$ of NSCLC patients.

Conclusions: The present study provides supportive evidence to show that both a high CEC count and a high sCD146 level at baseline correlate with poor prognosis and may be useful for the prediction of clinical outcome in patients undergoing surgery for NSCLC.

Despite the different therapeutic strategies developed to date, patients with non-small cell lung cancer (NSCLC) have a poor outcome. The 5-year overall survival (OS) of these patients is 20-25\% across all stages (Mountain, 2000; van Rens et al, 2000; Naruke et al, 2001; Goya et al, 2005; Blanchon et al, 2006; Pfannschmidt et al, 2007).
Metastasis is the primary cause of mortality in cancer patients (Siegel et al, 2013). In addition to the lack of effective treatment options, the absence of useful clinical indicators predicting prognosis and/or response to treatment may contribute to the poor prognosis of these patients. Tumour growth and metastasis depend on neovascularisation (Narazaki and Tosato, 2006;

*Correspondence: Dr P Hofman; E-mail: hofman.p@chu-nice.fr

Received 6 July 2013; revised 10 December 2013; accepted 12 December 2013; published online 28 January 2014

(c) 2014 Cancer Research UK. All rights reserved 0007-0920/14 
Yoneda et al, 2012). The process of tumour vascularisation is a potential target for new cancer therapies and can be a useful clinical marker (Ebos and Kerbel, 2011).

Circulating endothelial cells (CECs) are mature viable cells that are shed from the endothelium, circulate within the bloodstream and still exhibit proliferative capacity despite their terminal differentiation (Beerepoot et al, 2004). Recent studies demonstrated that CECs have an important role in tumour neovascularisation either at the primary or the metastatic site (Furstenberger et al, 2006; Goon et al, 2006; Narazaki and Tosato, 2006; Weis and Cheresh, 2011). The number of CECs and the extent of vascular damage are increased in a variety of vascular disorders including cardiovascular diseases, vasculitis and infectious diseases (Mutin et al, 1999; Mutunga et al, 2001; Woywodt et al, 2003; Beerepoot et al, 2004). It is noteworthy that the CEC count is increased in cancer patients compared with healthy subjects and may correlate with tumour progression (Mancuso et al, 2001; Beerepoot et al, 2004; Rowand et al, 2007). Moreover, the CEC count in cancer patients significantly decreased after surgical removal of the tumour and/or treatment with chemotherapy of the patient (Mancuso et al, 2001; Kawaishi et al, 2009). In addition, CEC kinetics and viability are promising predictors of the response to treatment with anti-angiogenic agents in patients with advanced breast cancer or colorectal cancer (Mancuso et al, 2006; Malka et al, 2012). Besides monitoring the anti-tumour activity, a marker such as CEC would reveal tumour growth and disease progression at an early stage in view of the known fragility of the tumour vasculature compared with the healthy vasculature (Strijbos et al, 2008). However, because of the technical difficulties and challenges associated with CEC measurement, data regarding the significance of CECs in patients with early-stage cancer are still lacking. An approach using an automated rare cell detection system has proven to be highly accurate and reliable in enumeration and isolation of CECs from peripheral blood (Rowand et al, 2007). However, very few studies to date have evaluated the clinical value of CECs in NSCLC patients using this methodology (Kawaishi et al, 2009).

In addition to the number of CECs in the blood, other biomarkers are thought to reflect the presence of angiogenesis and/ or vascular endothelial alteration, such as the concentration of soluble factors including soluble CD146 (sCD146) in the blood. CD146 (also referred to as MUC18, MCAM, Mel-CAM, S-Endo-1 and $\mathrm{P} 1 \mathrm{H} 12$ antigen) is a transmembrane glycoprotein that is constitutively expressed in the human endothelium, irrespectively of the anatomical localisation (Lehmann et al, 1989; Bardin et al, 1998; Bardin et al, 2003). CD146 is localised at the intercellular boundaries of endothelial cells and is involved in the control of cell cohesion (Bardin et al, 1996a; Shih, 1999; Bardin et al, 2001). Moreover, CD146 may have a key role in endothelial cell activity and angiogenesis (Kang et al, 2006). In addition to the membraneanchored form of CD146, a soluble form of CD146 (sCD146) has been identified using an ELISA assay in the supernatant of cultured human endothelial cells and in the plasma of healthy subjects (Bardin et al, 1998; Bardin et al, 2003; Furstenberger et al, 2005). The plasma concentration of sCD146 is modulated in inflammatory diseases associated with endothelial alterations (Bardin et al, 2006). However, there is no current data concerning the level of sCD146 in lung cancer patients.

In this setting, we hypothesised that CEC detachment from the vascular wall may be associated with the release of sCD146. The purpose of this study was: (1) to quantify CEC levels in patients undergoing surgery for NSCLC, (2) to quantify the plasma level of sCD146 in the same cohort of patients, (3) to compare the absolute number of CECs and the level of sCD146 in these patients, and, finally, (4) to correlate the results with different clinicopathological parameters and the outcome of patients.

\section{PATIENTS AND METHODS}

Patients. Seventy-four patients who underwent surgery for NSCLC (including seven patients with neoadjuvant chemotherapy) between January 2009 and January 2011 at the Pasteur Hospital (Department of Thoracic Surgery, University of Nice Sophia Antipolis, France) were included in this study. In addition, 20 patients with histologically and/or cytopathologically confirmed chemotherapy-naive small-cell lung cancer (SCLC) were enrolled in the study to test for the specificity of candidate biomarkers. Two control populations were included in the study: 20 patients with chronic obstructive pulmonary disease (COPD) (16 males, 4 females; mean age 68 years, range $55-77$ years; all smokers), as well as 42 age, sex and smoking status-matched healthy individuals (28 males, 14 females; mean age 57 years, range 21-74; 35 current smokers). After approval by the local Ethics Committees (Nice University Hospital Centre), written informed consent was obtained from participants after explaining the nature of the study and the study was performed according to the guidelines of the Declaration of Helsinki. Criteria for patient inclusion in the study were: NSCLC histology performed according to WHO criteria and the latest recommendations of the international association for the study of lung cancer (Travis et al, 2004, 2011), tumour stage I to IV (7th edition of UICC-TNM staging system, AJCC) (Goldstraw, 2009), patients treated with surgery of the primary tumour (wedge resection, lobectomy or pneumonectomy), availability of clinicopathological and outcome data, and no transbronchial and/or transparietal chest biopsies at least 15 days before surgery. The main clinical and pathological data are summarised in Table 1. In SCLC patients, blood samples were collected for analysis within 7 days before commencing treatment (baseline) chemotherapy cycle.

Methods. CellSearch technology (Veridex LLC, Raritan, NJ, USA) was carried out using previously described protocols (Strijbos et al, 2008; Malka et al, 2012). Briefly, $4 \mathrm{ml}$ of peripheral blood was taken before anaesthesia and collected in the CellSave preservative tubes (Veridex LLC). The first $2 \mathrm{ml}$ of peripheral blood was discarded to avoid contamination with endothelial cells from peripheral venules. Samples were maintained at room temperature and processed within $24 \mathrm{~h}$ after collection. The CellTracks AutoPrep System (Veridex LLC), the CellSearch Endothelial Cell Kit (Veridex LLC) and the CellSpotter Analyzer System (Veridex LLC) were used to enumerate the CECs. The CellSearch Endothelial Cell Kit was used for immunomagnetic enrichment using ferrofluids coupled to an anti-CD146 antibody. After enrichment, the following reagents were added: the nuclear dye 4,6-diamidino-2-phenylindole (DAPI), and fluorochrome-conjugated monoclonal antibodies: phycoerythrin-conjugated CD105, and allophycocyanin-conjugated CD45, a pan-leukocyte antigen was included to exclude haematopoietic cells from analysis. Analysis was done using image cytometry, in which CECs were defined as having an oval to elongated undamaged morphology and were $\mathrm{CD} 146$ + DAPI + CD105 + CD45 - (Supplementary Figure 1) (Rowand et al, 2007; Strijbos et al, 2008). The CEC count was expressed as the number of positive cells per $1 \mathrm{ml}$ of blood. Reproducibility was tested by performing two replicates of 20 different samples (Supplementary Figure 2).

In parallel, peripheral blood was drawn into EDTA tubes (Becton Dickinson, Le Pont-De-Claix, France). Within $1 \mathrm{~h}$, the tubes were subjected to centrifugation at $820 \mathrm{~g}$ for $10 \mathrm{~min}$. Transferred $1-\mathrm{ml}$ aliquots of the plasma to $1.5-\mathrm{ml}$ tubes was done followed by centrifugation at $16000 \mathrm{~g}$ for $10 \mathrm{~min}$ to pellet any remaining cellular debris. The supernatant was transferred to fresh tubes and stored at $-80^{\circ} \mathrm{C}$ until use.

Soluble CD146 levels were determined with a commercial enzyme-linked immunosorbent assay (CY-QUANT ELISA, 
Table 1. Clinical and pathological variables of the 53 patients with operable non-small cell lung carcinoma enrolled in the study

\begin{tabular}{|c|c|c|c|c|c|c|c|}
\hline \multirow[b]{2}{*}{ Variables } & \multirow[b]{2}{*}{ Overall n (\%) } & \multicolumn{2}{|c|}{ CEC count (per ml) } & \multirow[b]{2}{*}{$\boldsymbol{P}$-value } & \multicolumn{2}{|c|}{ sCD146 levels ( $\mathrm{ng} \mathrm{ml}^{-1}$ ) } & \multirow[b]{2}{*}{$\boldsymbol{P}$-value } \\
\hline & & Low & High & & Low & High & \\
\hline \multicolumn{8}{|l|}{ Age (years) ${ }^{a}$} \\
\hline Mean \pm s.d. & $65.2 \pm 8.6$ & $65.4 \pm 8.2$ & $65 \pm 9$ & 0.710 & $63.9 \pm 9.1$ & $66.5 \pm 8$ & 0.205 \\
\hline \multicolumn{8}{|l|}{ Gender $^{b}$} \\
\hline $\begin{array}{l}\text { Male } \\
\text { Female }\end{array}$ & $\begin{array}{l}54(73 \%) \\
20(27 \%)\end{array}$ & $\begin{array}{r}24(44 \%) \\
9(45 \%)\end{array}$ & $\begin{array}{l}30(56 \%) \\
11(55 \%)\end{array}$ & 0.585 & $\begin{array}{l}25(46 \%) \\
12(60 \%)\end{array}$ & $\begin{array}{r}29(54 \%) \\
8(40 \%)\end{array}$ & 0.216 \\
\hline \multicolumn{8}{|l|}{ ECOG PS } \\
\hline $\begin{array}{l}0 \\
1\end{array}$ & $\begin{array}{l}44(59 \%) \\
30(41 \%)\end{array}$ & $\begin{array}{l}24(55 \%) \\
19(63 \%)\end{array}$ & $\begin{array}{l}20(45 \%) \\
11(27 \%)\end{array}$ & 0.451 & $\begin{array}{l}26(59 \%) \\
18(60 \%)\end{array}$ & $\begin{array}{l}18(41 \%) \\
12(40 \%)\end{array}$ & 0.937 \\
\hline \multicolumn{8}{|l|}{ Baseline FEV 1} \\
\hline $\begin{array}{l}<2 \mathrm{~L} \\
\geqslant 2 \mathrm{~L}\end{array}$ & $\begin{array}{l}35(47 \%) \\
39(53 \%)\end{array}$ & $\begin{array}{l}23(66 \%) \\
26(67 \%)\end{array}$ & $\begin{array}{l}12(24 \%) \\
13(23 \%)\end{array}$ & 0.931 & $\begin{array}{l}25(71 \%) \\
23(59 \%)\end{array}$ & $\begin{array}{l}10(29 \%) \\
16(41 \%)\end{array}$ & 0.262 \\
\hline \multicolumn{8}{|l|}{$\mathrm{Hb}$ level $\left(\mathrm{gdl}^{-1}\right)$} \\
\hline $\begin{array}{l}<12 \\
\geqslant 12\end{array}$ & $\begin{array}{l}27(37 \%) \\
47(63 \%)\end{array}$ & $\begin{array}{l}18(67 \%) \\
32(68 \%)\end{array}$ & $\begin{array}{r}9(23 \%) \\
15(22 \%)\end{array}$ & 0.900 & $\begin{array}{l}16(59 \%) \\
35(74 \%)\end{array}$ & $\begin{array}{l}11(41 \%) \\
12(26 \%)\end{array}$ & 0.173 \\
\hline \multicolumn{8}{|l|}{ Smoking history ${ }^{b}$} \\
\hline $\begin{array}{l}\text { Never } \\
\text { Current and former }\end{array}$ & $\begin{array}{r}9(12 \%) \\
65(88 \%) \\
\end{array}$ & $\begin{array}{r}3(33 \%) \\
30(46 \%)\end{array}$ & $\begin{array}{r}6(67 \%) \\
35(54 \%)\end{array}$ & 0.361 & $\begin{array}{r}4(44 \%) \\
33(51 \%)\end{array}$ & $\begin{array}{r}5(56 \%) \\
32(49 \%)\end{array}$ & 0.500 \\
\hline \multicolumn{8}{|c|}{ Neoadjuvant chemotherapy } \\
\hline $\begin{array}{l}\text { No } \\
\text { Yes }\end{array}$ & $\begin{array}{c}67 \text { (91\%) } \\
7 \text { (9\%) }\end{array}$ & $\begin{array}{r}36(54 \%) \\
5(71 \%)\end{array}$ & $\begin{array}{r}31(46 \%) \\
2(29 \%)\end{array}$ & 0.370 & $\begin{array}{r}38(57 \%) \\
4(57 \%)\end{array}$ & $\begin{array}{r}29(23 \%) \\
3(23 \%)\end{array}$ & 0.982 \\
\hline \multicolumn{8}{|l|}{ Tumour size $^{a}$} \\
\hline Mean \pm s.d. & $3.8 \pm 2$ & $3.5 \pm 2.3$ & $4.1 \pm 1.8$ & 0.226 & $3.5 \pm 1.8$ & $3.9 \pm 2.1$ & 0.544 \\
\hline \multicolumn{8}{|l|}{ Histological subtypes ${ }^{b}$} \\
\hline $\begin{array}{l}\text { Adenocarcinoma } \\
\text { Squamous cell carcinoma }\end{array}$ & $\begin{array}{l}50(68 \%) \\
24(32 \%)\end{array}$ & $\begin{array}{l}23(46 \%) \\
10(42 \%)\end{array}$ & $\begin{array}{l}27(54 \%) \\
14(58 \%)\end{array}$ & 0.461 & $\begin{array}{l}25(50 \%) \\
12(50 \%)\end{array}$ & $\begin{array}{l}25 \text { (50\%) } \\
12(50 \%)\end{array}$ & 0.598 \\
\hline \multicolumn{8}{|l|}{ Histological grade ${ }^{b}$} \\
\hline $\begin{array}{l}\text { Well } \\
\text { Moderate } \\
\text { Poor }\end{array}$ & $\begin{array}{l}32(43 \%) \\
26(35 \%) \\
16(22 \%)\end{array}$ & $\begin{array}{r}16(50 \%) \\
9(35 \%) \\
8(50 \%)\end{array}$ & $\begin{array}{r}16(50 \%) \\
17(65 \%) \\
8(50 \%)\end{array}$ & 0.441 & $\begin{array}{r}14(44 \%) \\
14(54 \%) \\
9(56 \%)\end{array}$ & $\begin{array}{r}18(56 \%) \\
12(46 \%) \\
7(44 \%)\end{array}$ & 0.636 \\
\hline \multicolumn{8}{|l|}{ pTNM stage ${ }^{b}$} \\
\hline $\begin{array}{l}\text { I } \\
\text { II } \\
\text { III + IV }\end{array}$ & $\begin{array}{l}25(34 \%) \\
32(43 \%) \\
17(23 \%) \\
\end{array}$ & $\begin{array}{r}12(48 \%) \\
16(50 \%) \\
5(29 \%) \\
\end{array}$ & $\begin{array}{l}13(52 \%) \\
16(50 \%) \\
12(71 \%) \\
\end{array}$ & 0.342 & $\begin{array}{r}15(60 \%) \\
17(53 \%) \\
5(29 \%) \\
\end{array}$ & $\begin{array}{l}10(40 \%) \\
15(47 \%) \\
12(71 \%) \\
\end{array}$ & 0.129 \\
\hline $\begin{array}{l}\text { Abbreviations: } C E C=\text { circulatin } \\
\text { node-metastasis. The baseline } \\
\mathbf{a}_{T \text {-test. }} \\
\mathbf{b}_{\chi^{2} \text {-test. }}\end{array}$ & al cells; ECOG = & perative $O$ & $\begin{array}{l}\text { up; } F E V_{1}= \\
\text { s are showr }\end{array}$ & & & & $\mathrm{NM}=$ tumo \\
\hline
\end{tabular}

BioCytex, Marseille, France) according to the manufacturer's instructions. The ELISA assay was validated previously (Bardin et al, 1996b; Bardin et al, 1998; Bardin et al, 2003). Reproducibility was tested by performing two replicates of 20 different samples.

Statistical analysis. The $\chi^{2}$-test, the Fisher's exact test and the Mann-Whitney $U$-test were used to compare CECs and sCD146 levels according to the baseline clinicopathological characteristics.
A nonparametric correlation method (Spearman's Rank test) was used to evaluate the correlation between the CEC count and sCD146 plasma levels. The median time of follow-up was calculated according to the method of Schemper and Smith (1996). The survival time was calculated using Kaplan-Meier estimates and the differences between the progression-free (PFS) and OS curves, which were analysed with the log rank test. A Cox proportional hazard model was created to identify independent 
predictors of survival. Variables that were associated with survival with a $P$-value $<0.20$ in the univariate analysis were included in the multivariate regression. Differences were considered significant when a $P$-value was $<0.05$. All statistical evaluations were performed using SPSS for Windows software system, version 16.0.0 (SPSS, Chicago, IL, USA).

\section{RESULTS}

The baseline CEC count, the sCD146 level and correlation with clinicopathological parameters of patients. The detection and enumeration of CECs in the current cohort demonstrated a significantly higher baseline CEC count in the blood of NSCLC patients (median $114 \mathrm{CEC}$ per $\mathrm{ml}$; range, 22-661 per $\mathrm{ml}$ ) than in SCLC patients (median $46 \mathrm{CEC}$ per $\mathrm{ml}$; range, 26-94 per $\mathrm{ml}$ ), COPD patients (median 22 CEC per $\mathrm{ml}$; range, $7-37$ per $\mathrm{ml}$ ) or in healthy controls (median $3 \mathrm{CEC}$ per $\mathrm{ml}$; range, 1-13 per $\mathrm{ml}$ ) $(P<0.001$, Figure 1). Higher CEC count was observed in SCLC patients when compared with COPD patients or the healthy individuals (Figure 1). There was a tendency towards higher CEC count in COPD patients when compared with healthy subjects $(P=0.068)$. No significant difference was observed in the control group according to gender, age and tobacco status (data not shown).

Baseline sCD146 levels were significantly higher in NSCLC patients (median $275 \mathrm{ng} \mathrm{ml}^{-1}$, range, 89-905.4 $\mathrm{ng} \mathrm{ml}^{-1}$ ) as compared with SCLC patients (median $133.5 \mathrm{ng} \mathrm{ml}^{-1}$; range, $66-193 \mathrm{ng} \mathrm{ml}^{-1}$ ), COPD patients (median $107 \mathrm{ng} \mathrm{ml}^{-1}$; range, 60-180 $\mathrm{ng} \mathrm{ml}^{-1}$ ) and healthy subjects (median $78 \mathrm{ng} \mathrm{ml}^{-1}$; range, $20-349 \mathrm{ng} \mathrm{ml}^{-1}$ ) $(P<0.001$, Figure 1). Significant variations were observed between SCLC patients and COPD patients or healthy individuals (Figure 1). No significant difference was observed in the control group according to gender, age and tobacco status (data not shown).

A significant positive correlation was observed between the CEC count and sCD146 levels in NSCLC patients $(\rho=0.9, P=0.010$; Figure 2). Correlation of the coefficient values for variation of duplicate CECs and sCD146 samples from the same subject were $R^{2}=0.90$ and 0.92 , respectively.

Furthermore, we categorised the CEC count per ml and sCD146 levels as 'low' and 'high' using the 75th percentile of the interquartile range of the median value as the cutoff, as previously described (Malka et al, 2012). Accordingly, the range of low sCD146 levels was between 89 and $219.1 \mathrm{ng} \mathrm{ml}^{-1}$, and the range of high sCD146 levels was between 220.7 and $905.4 \mathrm{ng} \mathrm{ml}^{-1}$.

Among the NSCLC patients, there was no significant difference in the CEC count and sCD146 level according to age, gender, performance status, $\mathrm{FEV}_{1}$, $\mathrm{Hb}$ level, smoking history, tumour size, histological subtypes, tumour grade or pTNM stage $(P>0.05$, Table 1).

The CEC count, sCD146 levels and clinical outcome. At the last follow-up, 30 out of 74 (41\%) patients had local (55\%), regional $(27 \%)$ or distant (18\%) tumour recurrence and 22 out of $74(30 \%)$ patients died specifically from cancer progression.

The mean PFS was 36.9 months (95\% CI, 32.6-41.3). In the univariate analysis, the clinical factor that significantly associated with PFS was the pTNM stage $(P=0.012)$. The unadjusted survival analysis showed that patients with a high baseline CEC count and a high sCD146 level had poor PFS $(P<0.001, P<0.001$, respectively; Figure $3 \mathrm{~A}$ and $\mathrm{B})$ and worse $\mathrm{OS}(P=0.005, P=0.009$, respectively; Figure $3 \mathrm{D}$ and $\mathrm{E})$. This significance was even higher when adjusted for both endothelial biomarkers $(P<0.001$, respectively; Figure 3C and F). Patients with only one increased endothelial marker harboured intermediate outcomes.

The risk of progression was higher for patients with stage III + IV $(P=0.030)$, high CEC count $(P=0.001)$ and high sCD146 plasma level $(P=0.002$; Table 2$)$. The multivariate Cox analysis revealed that the pTNM stage $(P=0.086)$, the CEC count $(P=0.006)$ and sCD146 level $(P=0.020)$ were the prognostic factors that influence the OS of NSCLC patients (Table 2).

\section{DISCUSSION}

This study demonstrated that the baseline CEC count was markedly higher for NSCLC patients than for healthy individuals

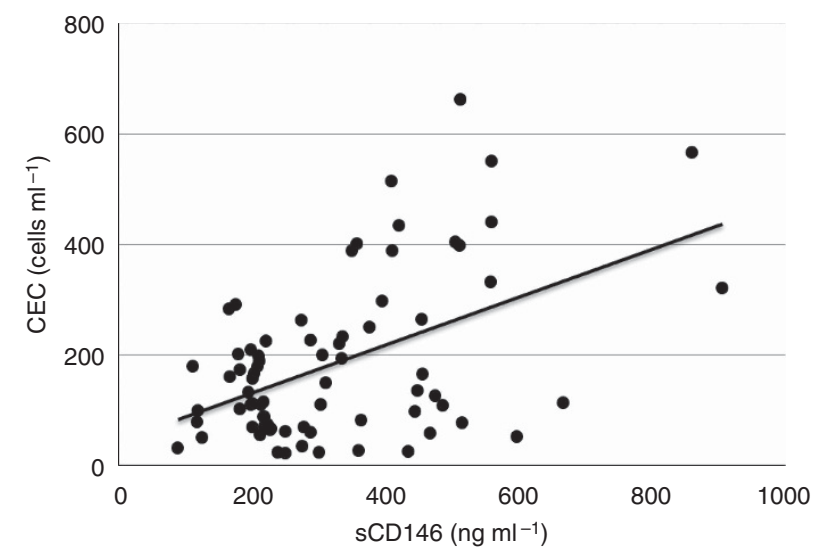

Figure 2. Correlation between the CEC count and the plasma level of sCD146 in 74 patients with operable NSCLC.
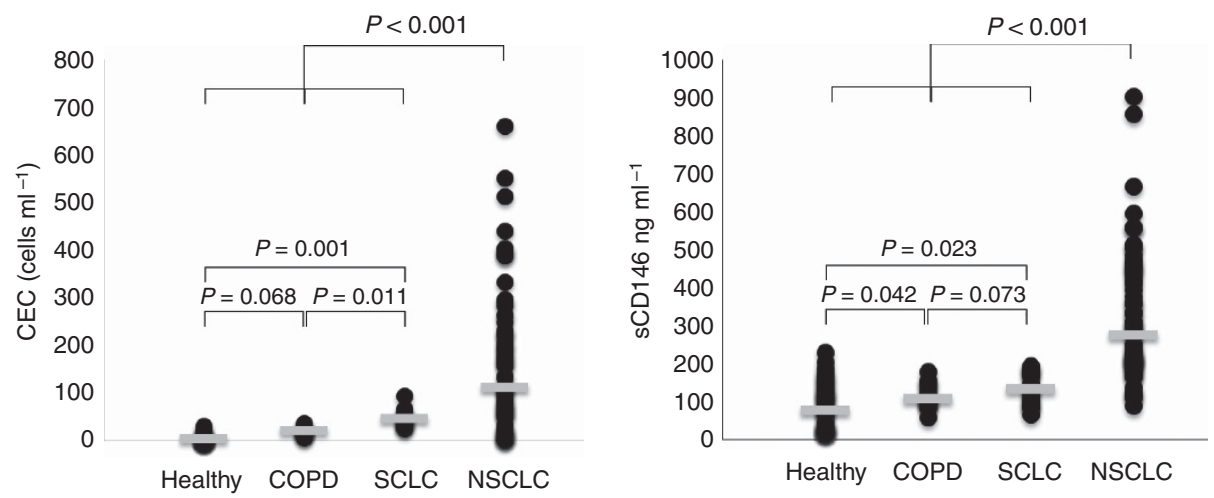

Figure 1. Distribution of the absolute CEC count per $\mathrm{ml}$ (left) and the sCD146 level (ng ml ${ }^{-1}$ ) (right) in 74 patients with operable NSCLC, 20 patients with SCLC and in controls (60 healthy individuals and 23 patients with COPD). The Mann-Whitney U-test was used for testing the significance. 
A

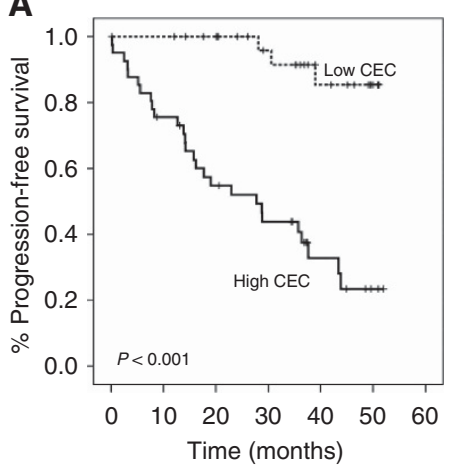

D

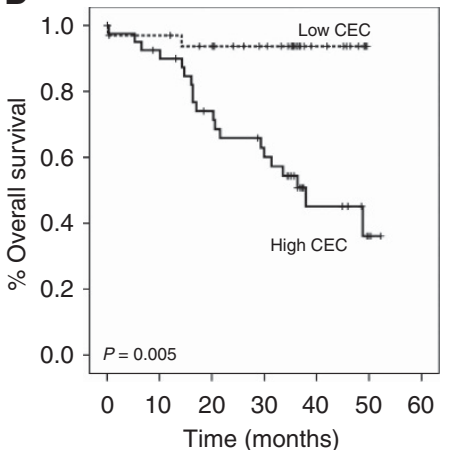

B

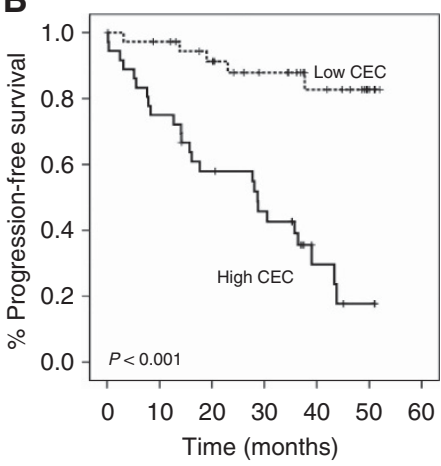

E

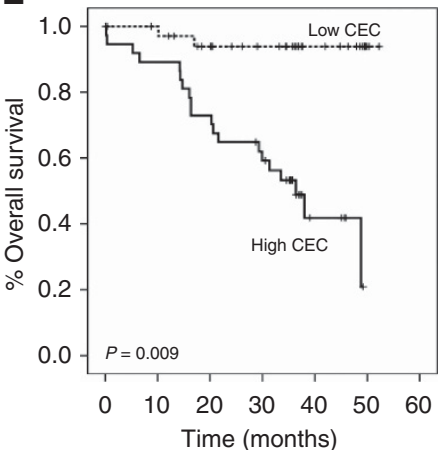

C

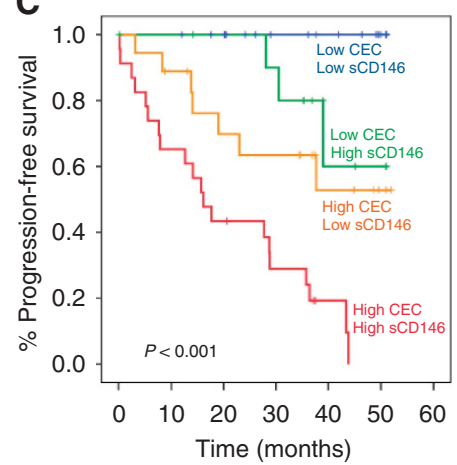

$\mathbf{F}$

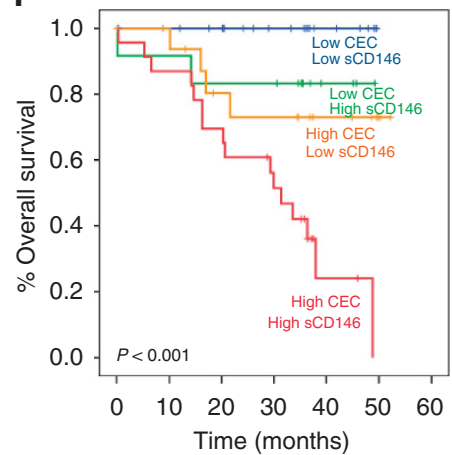

Figure 3. Kaplan-Meier curves of PFS (A, B and C) and overall survival (D, E and F) stratified according to the CEC count (left panels) and the SCD146 level (middle panels) or combined parameters (right panels).

Table 2. Multivariate analysis of prognostic factors identified in our study with PFS and OS as the end point in patients with operable NSCLC

\begin{tabular}{|c|c|c|c|}
\hline Prognostic factor & HR & $95 \% \mathrm{Cl}$ & $\boldsymbol{P}$-value ${ }^{\text {a }}$ \\
\hline \multicolumn{4}{|l|}{ PFS } \\
\hline \multicolumn{4}{|l|}{ pTNM stage } \\
\hline$I+I I v s I I I+I V$ & 0.172 & $0.035-0.844$ & 0.030 \\
\hline \multicolumn{4}{|l|}{ CEC count (per ml) } \\
\hline High vs low & 9.958 & $2.885-34.374$ & 0.001 \\
\hline \multicolumn{4}{|c|}{ sCD146 levels ( $\mathrm{ng} \mathrm{ml}^{-1}$ ) } \\
\hline High vs low & 6.018 & $1.954-18.537$ & 0.002 \\
\hline \multicolumn{4}{|l|}{ Overall survival } \\
\hline \multicolumn{4}{|l|}{ pTNM stage } \\
\hline$I+I I v s I I I+I V$ & 0.430 & $0.164-1.126$ & 0.086 \\
\hline \multicolumn{4}{|l|}{ CEC count (per ml) } \\
\hline High vs low & 8.478 & $1.846-38.931$ & 0.006 \\
\hline \multicolumn{4}{|c|}{ sCD146 levels (ng ml ${ }^{-1}$ ) } \\
\hline High vs low & 6.138 & $1.334-28.251$ & 0.020 \\
\hline $\begin{array}{l}\text { Abbreviations: } \mathrm{Cl}=\text { confi } \\
\text { a }_{P \text {-value }}<0.05 \text { statisticall }\end{array}$ & ival; HF & ratio. & \\
\hline
\end{tabular}

and COPD patients. Circulating endothelial cells are mature cells from the intima that are released into the circulation after vascular injury (D'Souza-Schorey and Clancy, 2012). This has been well documented in many human diseases, including different types of cancers. In cancer patients, the level of CECs is persistently higher over time than that of healthy individuals, and this increased level has been identified as a surrogate marker of neovascularisation and anti-angiogenic drug activity (Goon et al, 2006; Mancuso et al, 2006; Malka et al, 2012). We also observed an increased number of CECs in SCLC patients compared with healthy individuals and COPD patients. The CEC count was significantly lower than in NSCLC patients. As our SCLC population was limited in size, the value of CEC in SCLC patients should be further evaluated in larger series. Most importantly, our results show that the CEC count is associated with clinical outcome in NSCLC patients undergoing surgery, and thus may be a prognostic factor for this disease. In our study, patients with a high CEC count at baseline had a significantly worse PFS and OS. A majority of reports showed that high baseline CEC levels above the 75th percentile significantly correlated with prognosis, and could be useful as prognostic markers in patients with advanced NSCLC (Fleitas et al, 2010; Morita et al, 2011; Wang et al, 2013). In contrast, a study of 31 patients with advanced NSCLC treated with first-line carboplatin and paclitaxel reported that a CEC count of $>400 / 4 \mathrm{ml}$ at baseline showed a significantly improved PFS. However, no statistical data were presented in this study, which was limited in size and follow-up, to justify the choice of the cutoff (Kawaishi et al, 2009).

Endothelial progenitor cells (EPCs), which are circulating cells that originate from bone marrow, have the ability to form endothelial colonies in vitro, and to contribute to neovascularisation (Mancuso et al, 2003; Strijbos et al, 2008). In theory, cEPCs may be a more appropriate surrogate of tumour vascularisation. Subsequently, the pre-treatment level of cEPCs was proposed as a promising candidate biomarker for disease progression and prediction of clinical outcome in NSCLC (Dome et al, 2006; Fleitas et al, 2010; Nowak et al, 2010; Roodhart et al, 2010; Vroling et al, 2010). However, the clinical evaluation of cEPCs has been hampered by the extreme rarity of these cells and the lack of 
consensus on the surface marker phenotype and on the techniques used for cEPC enumeration (Peters et al, 2005; Wang et al, 2013). Nevertheless, a decrease in both CECs and cEPCs correlated with a longer PFS or OS in the majority of studies, before and after effective anti-angiogenic therapy and/or chemotherapy (Chu et al, 2012; Wang et al, 2013).

The present study showed that sCD146 levels were significantly higher in NSCLC patients than in healthy subjects. Previous studies have shown that sCD146 is detectable in the human blood and its level is modulated in different pathologies, such as inflammatory bowel diseases, vasculitis, pathologic pregnancies and chronic renal failure (Bardin et al, 2003; Pasquier et al, 2005; Bardin et al, 2006).

Furthermore, we showed a positive correlation between the CEC count and the sCD146 level, indicating that both biomarkers can be indirect surrogates of tumour vascularisation, as previously suggested for these individual markers (Monestiroli et al, 2001; Harhouri et al, 2010). For instance, sCD146 is involved in inflammation by specifically binding to monocytes and thereby stimulating transendothelial migration, as well as in angiogenesis (Bardin et al, 2009; Harhouri et al, 2010; Stalin et al, 2013). Thus, sCD146 exhibits chemotactic activity on different cell types involved in vessel formation, including endothelial cells. In addition, treatment of EPCs with sCD146 led to increased migration, proliferation and the capacity to form capillary-like structures. Finally, local treatment with sCD146 led to the recruitment of EPCs and to an increase in blood flow and neovessel formation (Harhouri et al, 2010). Interestingly, recent evidence suggested that SCD146, through inhibition of endothelial cell adhesion, may have a role in CEC migration and homing (Jiang et al, 2012; Wang and Yan, 2013). Moreover, the binding of CD146 to an anti-CD146 monoclonal antibody inhibited p38 mitogen-activated protein kinase phosphorylation, suppressed NF-kB activation and downregulated matrix metalloproteinase 9 and intercellular adhesion molecule 1 expression, suggesting that the CD146/NF-kB axis is critical in endothelial cell migration, angiogenesis and tumour metastasis (Ouhtit et al, 2009).

We further investigated whether sCD146 can assist in determining the outcome of NSCLC surgical patients at baseline. Our results support the hypothesis that CEC counts together with sCD146 levels are associated with clinical outcome in NSCLC patients undergoing surgery. We showed that patients with a high CEC count and an elevated sCD146 level at baseline had a significantly worse PFS and OS, whereas patients with a single high endothelial marker harboured intermediate outcomes, suggesting a possible synergistic effect on cancer progression.

CD146 is a member of the immunoglobulin superfamily that was originally identified as a melanoma marker and has a role in tumour metastasis (Shih, 1999). Recent data suggest that CD146 may be involved in tumour development and may influence tumour prognosis in a number of solid tumours (Liu et al, 2012; Zeng et al, 2012b; Kapoor, 2013). It is expressed in a high proportion of NSCLC and might be predictive of shortened patient survival in lung adenocarcinomas (Kristiansen et al, 2003; Oka et al, 2012). Moreover, CD146 promotes cancer progression by induction of epithelial-mesenchymal transition, a critical step in tumour metastasis, through modulating the remodelling of cytoskeleton (Luo et al, 2012; Zeng et al, 2012a).

In conclusion, our findings demonstrate that the CEC count and the sCD146 plasma level might be suitable biomarkers at baseline for predicting outcome of patients with NSCLC following surgical resection.

\section{CONFLICT OF INTEREST}

The authors declare no conflict of interest.

\section{REFERENCES}

Bardin N, Anfosso F, Masse JM, Cramer E, Sabatier F, Le Bivic A, Sampol J, Dignat-George F (2001) Identification of CD146 as a component of the endothelial junction involved in the control of cell-cell cohesion. Blood 98(13): 3677-3684.

Bardin N, Blot-Chabaud M, Despoix N, Kebir A, Harhouri K, Arsanto JP, Espinosa L, Perrin P, Robert S, Vely F, Sabatier F, Le Bivic A, Kaplanski G, Sampol J, Dignat-George F (2009) CD146 and its soluble form regulate monocyte transendothelial migration. Arterioscler Thromb Vasc Biol 29(5): 746-753.

Bardin N, Frances V, Combes V, Sampol J, Dignat-George F (1998) CD146: biosynthesis and production of a soluble form in human cultured endothelial cells. FEBS Lett 421(1): 12-14.

Bardin N, Frances V, Lesaule G, Horschowski N, George F, Sampol J (1996a) Identification of the S-Endo 1 endothelial-associated antigen. Biochem Biophys Res Commun 218(1): 210-216.

Bardin N, George F, Mutin M, Brisson C, Horschowski N, Frances V, Lesaule G, Sampol J (1996b) S-Endo 1, a pan-endothelial monoclonal antibody recognizing a novel human endothelial antigen. Tissue Antigens 48(5): 531-539.

Bardin N, Moal V, Anfosso F, Daniel L, Brunet P, Sampol J, Dignat George F (2003) Soluble CD146, a novel endothelial marker, is increased in physiopathological settings linked to endothelial junctional alteration. Thromb Haemost 90(5): 915-920.

Bardin N, Reumaux D, Geboes K, Colombel JF, Blot-Chabaud M, Sampol J, Duthilleul P, Dignat-George F (2006) Increased expression of CD146, a new marker of the endothelial junction in active inflammatory bowel disease. Inflamm Bowel Dis 12(1): 16-21.

Beerepoot LV, Mehra N, Vermaat JS, Zonnenberg BA, Gebbink MF, Voest EE (2004) Increased levels of viable circulating endothelial cells are an indicator of progressive disease in cancer patients. Ann Oncol 15(1): 139-145.

Blanchon F, Grivaux M, Asselain B, Lebas FX, Orlando JP, Piquet J, Zureik M (2006) 4-year mortality in patients with non-small-cell lung cancer: development and validation of a prognostic index. Lancet Oncol 7(10): 829-836.

Chu TQ, Ding H, Garfield DH, Gu AQ, Pei J, Du WD, Han BH (2012) Can determination of circulating endothelial cells and serum caspase-cleaved CK18 predict for response and survival in patients with advanced non-small-cell lung cancer receiving endostatin and paclitaxel-carboplatin chemotherapy? a retrospective study. J Thorac Oncol 7(12): 1781-1789.

D'Souza-Schorey C, Clancy JW (2012) Tumor-derived microvesicles: shedding light on novel microenvironment modulators and prospective cancer biomarkers. Genes Dev 26(12): 1287-1299.

Dome B, Timar J, Dobos J, Meszaros L, Raso E, Paku S, Kenessey I, Ostoros G, Magyar M, Ladanyi A, Bogos K, Tovari J (2006) Identification and clinical significance of circulating endothelial progenitor cells in human non-small cell lung cancer. Cancer Res 66(14): 7341-7347.

Ebos JM, Kerbel RS (2011) Antiangiogenic therapy: impact on invasion, disease progression, and metastasis. Nat Rev Clin Oncol 8(4): 210-221.

Fleitas T, Martinez-Sales V, Gomez-Codina J, Martin M, Reynes G (2010) Circulating endothelial and endothelial progenitor cells in non-small-cell lung cancer. Clin Transl Oncol 12(8): 521-525.

Furstenberger G, von Moos R, Lucas R, Thurlimann B, Senn HJ, Hamacher J, Boneberg EM (2006) Circulating endothelial cells and angiogenic serum factors during neoadjuvant chemotherapy of primary breast cancer. Br J Cancer 94(4): 524-531.

Furstenberger G, von Moos R, Senn HJ, Boneberg EM (2005) Real-time PCR of CD146 mRNA in peripheral blood enables the relative quantification of circulating endothelial cells and is an indicator of angiogenesis. Br J Cancer 93(7): 793-798.

Goldstraw P (2009) The 7th Edition of TNM in Lung Cancer: what now? $J$ Thorac Oncol 4(6): 671-673.

Goon PK, Lip GY, Boos CJ, Stonelake PS, Blann AD (2006) Circulating endothelial cells, endothelial progenitor cells, and endothelial microparticles in cancer. Neoplasia 8(2): 79-88.

Goya T, Asamura H, Yoshimura H, Kato H, Shimokata K, Tsuchiya R, Sohara Y, Miya T, Miyaoka E (2005) Prognosis of 6644 resected non-small cell lung cancers in Japan: a Japanese lung cancer registry study. Lung Cancer 50(2): 227-234. 
Harhouri K, Kebir A, Guillet B, Foucault-Bertaud A, Voytenko S, Piercecchi-Marti MD, Berenguer C, Lamy E, Vely F, Pisano P, Ouafik L, Sabatier F, Sampol J, Bardin N, Dignat-George F, Blot-Chabaud M (2010) Soluble CD146 displays angiogenic properties and promotes neovascularization in experimental hind-limb ischemia. Blood 115(18): 3843-3851.

Jiang T, Zhuang J, Duan H, Luo Y, Zeng Q, Fan K, Yan H, Lu D, Ye Z, Hao J, Feng J, Yang D, Yan X (2012) CD146 is a coreceptor for VEGFR-2 in tumor angiogenesis. Blood 120(11): 2330-2339.

Kang Y, Wang F, Feng J, Yang D, Yang X, Yan X (2006) Knockdown of CD146 reduces the migration and proliferation of human endothelial cells. Cell Res 16(3): 313-318.

Kapoor S (2013) CD146 expression and its close relationship to tumor progression in systemic malignancies besides gall bladder carcinomas. Tumour Biol 34(2): 1273-1274.

Kawaishi M, Fujiwara Y, Fukui T, Kato T, Yamada K, Ohe Y, Kunitoh H, Sekine I, Yamamoto N, Nokihara H, Watabe T, Shimoda Y, Arao T, Nishio K, Tamura T, Koizumi F (2009) Circulating endothelial cells in non-small cell lung cancer patients treated with carboplatin and paclitaxel. J Thorac Oncol 4(2): 208-213.

Kristiansen G, Yu Y, Schluns K, Sers C, Dietel M, Petersen I (2003) Expression of the cell adhesion molecule CD146/MCAM in non-small cell lung cancer. Anal Cell Pathol 25(2): 77-81.

Lehmann JM, Riethmuller G, Johnson JP (1989) MUC18, a marker of tumor progression in human melanoma, shows sequence similarity to the neural cell adhesion molecules of the immunoglobulin superfamily. Proc Natl Acad Sci USA 86(24): 9891-9895.

Liu WF, Ji SR, Sun JJ, Zhang Y, Liu ZY, Liang AB, Zeng HZ (2012) CD146 expression correlates with epithelial-mesenchymal transition markers and a poor prognosis in gastric cancer. Int J Mol Sci 13(5): 6399-6406.

Luo Y, Zheng C, Zhang J, Lu D, Zhuang J, Xing S, Feng J, Yang D, Yan X (2012) Recognition of CD146 as an ERM-binding protein offers novel mechanisms for melanoma cell migration. Oncogene 31(3): 306-321.

Malka D, Boige V, Jacques N, Vimond N, Adenis A, Boucher E, Pierga JY, Conroy T, Chauffert B, Francois E, Guichard P, Galais MP, Cvitkovic F, Ducreux M, Farace F (2012) Clinical value of circulating endothelial cell levels in metastatic colorectal cancer patients treated with first-line chemotherapy and bevacizumab. Ann Oncol 23(4): 919-927.

Mancuso P, Burlini A, Pruneri G, Goldhirsch A, Martinelli G, Bertolini F (2001) Resting and activated endothelial cells are increased in the peripheral blood of cancer patients. Blood 97(11): 3658-3661.

Mancuso P, Colleoni M, Calleri A, Orlando L, Maisonneuve P, Pruneri G, Agliano A, Goldhirsch A, Shaked Y, Kerbel RS, Bertolini F (2006) Circulating endothelial-cell kinetics and viability predict survival in breast cancer patients receiving metronomic chemotherapy. Blood 108(2): 452-459.

Mancuso P, Rabascio C, Bertolini F (2003) Strategies to investigate circulating endothelial cells in cancer. Pathophysiol Haemost Thromb 33(5-6): 503-506.

Monestiroli S, Mancuso P, Burlini A, Pruneri G, Dell'Agnola C, Gobbi A, Martinelli G, Bertolini F (2001) Kinetics and viability of circulating endothelial cells as surrogate angiogenesis marker in an animal model of human lymphoma. Cancer Res 61(11): 4341-4344.

Morita R, Sato K, Nakano M, Miura H, Odaka H, Nobori K, Kosaka T, Sano M, Watanabe H, Shioya T, Ito H (2011) Endothelial progenitor cells are associated with response to chemotherapy in human non-small-cell lung cancer. J Cancer Res Clin Oncol 137(12): 1849-1857.

Mountain CF (2000) The international system for staging lung cancer. Semin Surg Oncol 18(2): 106-115.

Mutin M, Canavy I, Blann A, Bory M, Sampol J, Dignat-George F (1999) Direct evidence of endothelial injury in acute myocardial infarction and unstable angina by demonstration of circulating endothelial cells. Blood 93(9): 2951-2958.

Mutunga M, Fulton B, Bullock R, Batchelor A, Gascoigne A, Gillespie JI, Baudouin SV (2001) Circulating endothelial cells in patients with septic shock. Am J Respir Crit Care Med 163(1): 195-200.

Narazaki M, Tosato G (2006) Tumor cell populations differ in angiogenic activity: a model system for spontaneous angiogenic switch can tell us why. J Natl Cancer Inst 98(5): 294-295.

Naruke T, Tsuchiya R, Kondo H, Asamura H (2001) Prognosis and survival after resection for bronchogenic carcinoma based on the 1997 TNM-staging classification: the Japanese experience. Ann Thorac Surg 71(6): 1759-1764.
Nowak K, Rafat N, Belle S, Weiss C, Hanusch C, Hohenberger P, Beck G (2010) Circulating endothelial progenitor cells are increased in human lung cancer and correlate with stage of disease. Eur J Cardiothorac Surg 37(4): 758-763.

Oka S, Uramoto H, Chikaishi Y, Tanaka F (2012) The expression of CD146 predicts a poor overall survival in patients with adenocarcinoma of the lung. Anticancer Res 32(3): 861-864.

Ouhtit A, Gaur RL, Abd Elmageed ZY, Fernando A, Thouta R, Trappey AK, Abdraboh ME, El-Sayyad HI, Rao P, Raj MG (2009) Towards understanding the mode of action of the multifaceted cell adhesion receptor CD146. Biochim Biophys Acta 1795(2): 130-136.

Pasquier E, Bardin N, De Saint Martin L, Le Martelot MT, Bohec C, Roche S, Mottier D, Dignat-George F (2005) The first assessment of soluble CD146 in women with unexplained pregnancy loss. A new insight? Thromb Haemost 94(6): 1280-1284.

Peters BA, Diaz LA, Polyak K, Meszler L, Romans K, Guinan EC, Antin JH, Myerson D, Hamilton SR, Vogelstein B, Kinzler KW, Lengauer C (2005) Contribution of bone marrow-derived endothelial cells to human tumor vasculature. Nat Med 11(3): 261-262.

Pfannschmidt J, Muley T, Bulzebruck H, Hoffmann H, Dienemann H (2007) Prognostic assessment after surgical resection for non-small cell lung cancer: experiences in 2083 patients. Lung Cancer 55(3): 371-377.

Roodhart JM, Langenberg MH, Vermaat JS, Lolkema MP, Baars A, Giles RH, Witteveen EO, Voest EE (2010) Late release of circulating endothelial cells and endothelial progenitor cells after chemotherapy predicts response and survival in cancer patients. Neoplasia 12(1): 87-94.

Rowand JL, Martin G, Doyle GV, Miller MC, Pierce MS, Connelly MC, Rao C, Terstappen LW (2007) Endothelial cells in peripheral blood of healthy subjects and patients with metastatic carcinomas. Cytometry A 71(2): 105-113.

Schemper M, Smith TL (1996) A note on quantifying follow-up in studies of failure time. Control Clin Trials 17(4): 343-346.

Shih IM (1999) The role of CD146 (Mel-CAM) in biology and pathology. J Pathol 189(1): 4-11.

Siegel R, Naishadham D, Jemal A (2013) Cancer statistics, 2013. CA Cancer J Clin 63(1): 11-30.

Stalin J, Harhouri K, Hubert L, Subrini C, Lafitte D, Lissitzky JC, Elganfoud N, Robert S, Foucault-Bertaud A, Kaspi E, Sabatier F, Aurrand-Lions M, Bardin N, Holmgren L, Dignat-George F, Blot-Chabaud M (2013) Soluble melanoma cell adhesion molecule (sMCAM/sCD146) promotes angiogenic effects on endothelial progenitor cells through angiomotin. J Biol Chem 288(13): 8991-9000.

Strijbos MH, Rao C, Schmitz PI, Kraan J, Lamers CH, Sleijfer S, Terstappen LW, Gratama JW (2008) Correlation between circulating endothelial cell counts and plasma thrombomodulin levels as markers for endothelial damage. Thromb Haemost 100(4): 642-647.

Travis WD, Brambilla E, Noguchi M, Nicholson AG, Geisinger KR, Yatabe Y, Beer DG, Powell CA, Riely GJ, Van Schil PE, Garg K, Austin JH, Asamura H, Rusch VW, Hirsch FR, Scagliotti G, Mitsudomi T, Huber RM, Ishikawa Y, Jett J, Sanchez-Cespedes M, Sculier JP, Takahashi T, Tsuboi M, Vansteenkiste J, Wistuba I, Yang PC, Aberle D, Brambilla C, Flieder D, Franklin W, Gazdar A, Gould M, Hasleton P, Henderson D, Johnson B, Johnson D, Kerr K, Kuriyama K, Lee JS, Miller VA, Petersen I, Roggli V, Rosell R, Saijo N, Thunnissen E, Tsao M, Yankelewitz D (2011) International association for the study of lung cancer/american thoracic society/european respiratory society international multidisciplinary classification of lung adenocarcinoma. J Thorac Oncol 6(2): 244-285.

Travis WD BE, Müller-Hermelink HK, Harris CC (2004) WHO histological classification of tumors of the lung. In: World Health Organization Classification of Tumours. Pathology and Genetics of Tumours of the Lung, Pleura, Thymus and Heart. IARC Press: Lyon, p 342.

van Rens MT, de la Riviere AB, Elbers HR, van Den Bosch JM (2000) Prognostic assessment of 2,361 patients who underwent pulmonary resection for non-small cell lung cancer, stage I, II, and IIIA. Chest 117(2): 374-379.

Vroling L, Lind JS, de Haas RR, Verheul HM, van Hinsbergh VW, Broxterman HJ, Smit EF (2010) CD133 + circulating haematopoietic progenitor cells predict for response to sorafenib plus erlotinib in non-small cell lung cancer patients. Br J Cancer 102(2): 268-275.

Wang J, Xiao J, Wei X, Wang L, Lin L, Liu Z, Wang X, Sun B, Li K (2013) Circulating endothelial cells and tumor blood volume as predictors in lung cancer. Cancer Sci 104(4): 445-452. 
Wang Z, Yan X (2013) CD146, a multi-functional molecule beyond adhesion. Cancer Lett 330(2): 150-162.

Weis SM, Cheresh DA (2011) Tumor angiogenesis: molecular pathways and therapeutic targets. Nat Med 17(11): 1359-1370.

Woywodt A, Streiber F, de Groot K, Regelsberger H, Haller H, Haubitz M (2003) Circulating endothelial cells as markers for ANCA-associated small-vessel vasculitis. Lancet 361(9353): 206-210.

Yoneda K, Tanaka F, Kondo N, Orui H, Hashimoto M, Takuwa T, Matsumoto S, Okumura Y, Tsubota N, Sato A, Tsujimura T, Kuribayashi K, Fukuoka K, Nakano T, Hasegawa S (2012) Circulating endothelial cell (CEC) as a diagnostic and prognostic marker in malignant pleural mesothelioma (MPM). Ann Surg Oncol 19(13): 4229-4237.

Supplementary Information accompanies this paper on British Journal of Cancer website (http://www.nature.com/bjc)
Zeng G, Cai S, Liu Y, Wu GJ (2012a) METCAM/MUC18 augments migration, invasion, and tumorigenicity of human breast cancer SK-BR-3 cells. Gene 492(1): 229-238.

Zeng Q, Li W, Lu D, Wu Z, Duan H, Luo Y, Feng J, Yang D, Fu L, Yan X (2012b) CD146, an epithelial-mesenchymal transition inducer, is associated with triple-negative breast cancer. Proc Natl Acad Sci USA 109(4): 1127-1132.

This work is published under the standard license to publish agreement. After 12 months the work will become freely available and the license terms will switch to a Creative Commons AttributionNonCommercial-Share Alike 3.0 Unported License. 